ing of the lesions would have been more rapid in the drugtreated group.

A long-term follow-up of patients with pain lasting longer than the 28-day study was carried out. This showed that the group was significantly older than those patients whose pain went during the 28-day observation period and the final disappearance of pain was at about the same time in both the control and treated groups.

I thank the following family doctors who collaborated in the study: Drs. W. V. Anderson, D. M. Baker, H. G. Barnes, A. Belton, J. Bennion-Pedley, W. Benson, J. D. Broadbent, I. E. CarnegieBrown, K. Browne, J. M. Cane, L. J. Clark-Wilson, G. F. Cockings, P. J. Constable, M. E. M. Cook, J. F. Donald, R. E. Dreaper, M. Drury, A. K. N. Dunton, G. S. Dyker, D. G. Emery, R. L. Ferguson, C. B. Findlay, D. N. Fitzgerald, D. G. Garvie, M. Gringras, N. K. Gostick, M. S. Harvey, D. W. W. Hendry, E. M. Holzer, P. Hopkins, R. C. G. Hughes, J. G. Hunter, G. M. Ingall, G. Jessup, R. A. Lee, G. W. Lewis, J. Lloyd, S. Maneksha, T. C. Mayer, R. N. Midha, P. Miller, R. Million, J. R. Morton,
S. E. Newton, P. Osborne, G. W. Phillips, G. S. Plaut, A. M. W. Porter, D. C. Rawlins, K. D. Robinson, A. K. Ross, W. A. Rushford, M. Schapira, R. H. Schulz, F. S. Shepherd, E. M. Sklar, I. W. Stoddart, C. M. Stretton, B. A. Thompson, F. Walt, D. Waxman, J. Wilkinson, H. N. Williams, I. W. Williams, J. McA. Williams, K. Woodbridge, and I. Wynne-Hughes.

I am grateful to Dr. MacCallum and his staff for the virus antibody estimations.

I thank Dr. B. Juel-Jensen for advice in planning the study, and Dr. E. Lewis-Faning for the statistical analysis.

\section{References}

Davies, W. L., et al. (1964). Science, 144, 862.

Eggers, H. J. (1970). Annals of the New York Academy of Sciences, 173, 417. Galbraith, A. W., Oxford, J. S., Schild, G. C., and Watson, G. I. (1969). Lancet, $2,1026$.

Hornick, R. B., Togo, Y., Mahler, S., and Iezzoni, D. G. (1969). Bulletin of the World Health Organization, 41, 671.

Togo, Y., Hornick, R. B., and Dawkins, A. T. (1968). Journal of the American Medical Association, 203, 1089

Vernier, V. G., et al. (1969). Toxicology and Applied Pharmacology, 15, 642.

\title{
Incidence of Anticonvulsant Osteomalacia and Effect of Vitamin D: Controlled Therapeutic Trial
}

\begin{abstract}
Summary
The bone mineral content (B.M.C.) in both forearms (related to total body calcium) was measured by photon absorptiometry for a controlled therapeutic trial in a representative sample of epileptic outpatients, comprising 226 patients treated with one or two major anticonvulsant drugs (phenytoin, phenobarbitone, primidone).

Initially the mean B.M.C. value for all epileptic patients was $87 \%$ of normal. During treatment with 2,000 international units of vitamin $D_{2}$ daily for three months an average B.M.C. increase of $4 \%$ was found, whereas the B.M.C. values remained unchanged in the placebo group and in the control groups. The incidence of hypocalcaemia and raised serum alkaline phosphatase was $12 \%$ and $43 \%$ respectively. The biochemical indices of osteomalacia were related to B.M.C. These results indicate that epileptic patients should be closely supervised for the occurrence of anticonvulsant osteomalacia, and, possibly, receive prophylactic treatment with vitamin $D$.
\end{abstract}

\section{Introduction}

Biochemical findings suggesting osteomalacia are quite often seen in epileptic patients treated with major anticonvulsant drugs (Wright, 1965; Schmid, 1967; Kruse, 1968; Dent et al.,

Glostrup Hospital, 2600 Glostrup, Denmark

CLAUS CHRISTIANSEN, CAND.MED., Assistant Physician, Department

MOGENS LUND, M.D., Physician-in-Chief, Department of Neurology

Aalborg Sygehus Syd, 9000 Aalborg, Denmark

PAUL RøDBRO, M.D., Physician-in-Chief, Department of Clinical Physiology
1970; Richens and Rowe, 1970; Hunter et al., 1971). The suggestion was made that induction of liver enzymes concerned with hydroxylation of vitamin D might be responsible for this disturbance of calcium metabolism (Richens and Rowe, 1970). Several findings have supported this hypothesis. The urinary excretion of glucaric acid, which is an index of liver-enzyme induction, correlates inversely with the serum calcium levels in epileptics (Hunter et al., 1971). Other investigations have shown low serum levels of 25-hydroxycholecalciferol (Hahn et al., 1972; Stamp et al., 1972), the main circulating metabolite of vitamin $\mathrm{D}_{3}$ (Ponchon and DeLuca, 1969).

With regard to the clinical significance of these drug-induced phenomena, a number of authors have reported radiological signs of rickets (Kruse, 1968; Berger and Munde, 1970; Lussier-Lazaroff and Fletcher, 1971; Lässker et al., 1971; Stögmann, 1971). However, the published reports disagree considerably as to the incidence of anticonvulsant rickets in epileptic children. This may be due to the inborn qualitative nature of the radiological examination. Bone biopsy has been done in only a few patients (Dent et al., 1970), and this method is similarly difficult to quantitate. It is possible to express the bone mineral content quantitatively by means of photon absorptiometry, and this has been used to show a low bone mineral content in small groups of epileptic patients (Linde et al., 1971; Christiansen et al., 1972, 1973).

Though most epileptics are outpatients the major reports on anticonvulsant osteomalacia have concerned inpatients (Richens and Rowe, 1970; Hunter et al., 1971; Stamp et al., 1972). Naturally, the question arises whether the large number of patients on anticonvulsant therapy should be treated with vitamin $\mathrm{D}$, and if this is so what dose of vitamin $\mathrm{D}$ should the patient receive? A subsidiary question might be: which patients should have vitamin $\mathrm{D}$, and how should they be selected?

Before these questions can be answered it is necessary to decide on a method of quantitating bone demineralization in anticonvulsant osteomalacia, and to apply it to a large, representative sample of epileptic outpatients before and after treatment with therapeutic doses of vitamin $D$. To minimize unwanted influences the therapeutic trial should be carried out in a 
controlled way over a reasonably short time-preferably during the winter.

We report here a controlled therapeutic trial in epileptic outpatients, where photon absorptiometry was used to evaluate bone mineral content (B.M.C.). Furthermore, the serum levels of calcium and alkaline phosphatase were determined in order to compare the biochemical and the bone indices of osteomalacia.

\section{Epileptic Patients and Control Subjects}

\section{EPILEPTIC PATIENTS}

A total of 249 epileptics who attended the epilepsy clinic at Glostrup Hospital at regular intervals were invited to take part in the investigation. All fulfilled the following criteria: they were outpatients receiving treatment with one or two major anticonvulsant drugs (phenytoin, phenobarbitone, and primidone); aged between 21 and 70 years; there were no symptoms of digestive or renal diseases; all had a normal serum creatinine value; most were fully capable of doing their daily work, and none were disabled. Of these 249 patients 23 declined the invitation. This left 226 who agreed to participate after the nature of the trial was explained to them. The sex and age of the patients, the dose of anticonvulsant drugs, serum levels of anticonvulsants, and duration of treatment are shown in table I. According to the anticonvulsant therapy the 226 patients were divided into three groups.

Group $A$ comprised 151 patients treated with phenytoin.

Group $B$ comprised 12 patients treated with phenobarbitone and four patients treated with primidone (the action of primidone is due to the metabolic conversion to phenobarbitone, Bogan and Smith, 1968).

Group $C$ comprised 47 patients treated with phenytoin plus phenobarbitone, and 12 patients treated with phenytoin plus primidone.

\section{CONTROL SUBJECTS}

Three groups of control subjects were investigated. None had symptoms of digestive or renal diseases, and all had a normal serum creatinine value.

Group 1 (127 subjects).-The age and sex distribution are given in table II (mean age: men 42 years, women 43 years). This group served as a reference group of bone mineral content measured as described below.

Group 2 (95 subjects, randomly selected from the blood-donor corps at viostrup Hospital).- The age and sex distribution are given in tabla III (mean age: men 44 years, women 41 years). This group servid as a reference group of serum calcium and serum alkaline phosphatase levels.

Group 3 (20 subjects, all members of the laboratory staff).Ten women and 10 men aged 21 to 33 years (mean 28 years) agreed to participate in the controlled therapeutic trial (see under Procedure). Preliminary results from this group have previously been published (Christiansen et al., 1973).

\section{Methods}

BONE MINERAL CONTENT (B.M.C.)

The bone mineral content was determined by direct photon absorptiometry on both forearms (fig. 1). Antebrachium is fixed in a Plexiglass container filled with distilled water. The source of radiation $\left(25 \mathrm{mCi}^{125 \mathrm{I}}\right)$ and the detector are fixed in a holder

TABle I-Sex, Age, Dose of Anticonvulsant Drugs, Serum Levels of Anticonvulsant, and Duration of Treatment in 226 Epileptics

\begin{tabular}{|c|c|c|c|c|c|c|c|c|c|c|c|c|c|c|c|}
\hline \multirow{3}{*}{$\begin{array}{l}\text { Treatment } \\
\text { Group }\end{array}$} & \multicolumn{3}{|c|}{ No. of Patients } & \multicolumn{4}{|c|}{ Age (years) } & \multicolumn{2}{|c|}{$\begin{array}{l}\text { Anticonvulsant } \\
\text { Dose (mg/kg) }\end{array}$} & \multicolumn{4}{|c|}{$\begin{array}{c}\text { Serum Level of } \\
\text { Anticonvulsant (mg/1.) }\end{array}$} & \multicolumn{2}{|c|}{$\begin{array}{c}\text { Duration of } \\
\text { Treatment (years) }\end{array}$} \\
\hline & \multirow{2}{*}{ Total } & \multirow{2}{*}{ Men } & \multirow{2}{*}{ Women } & \multicolumn{2}{|c|}{ Men } & \multicolumn{2}{|c|}{ Women } & \multirow{2}{*}{ Mean } & \multirow{2}{*}{ Range } & \multicolumn{2}{|c|}{ Before Trial } & \multicolumn{2}{|c|}{ After Trial } & \multirow{2}{*}{ Mean } & \multirow{2}{*}{ Range } \\
\hline & & & & Mean & Range & $\overline{\text { Mean }}$ & Range & & & $\overline{\text { Mean }}$ & Range & $\overline{\text { Mean }}$ & Range & & \\
\hline Group A & 151 & 92 & 59 & 44 & $21-70$ & 39 & $21-70$ & 5,1 & $2,6-10,5^{*}$ & 8,0 & $1-27^{*}$ & 9,4 & $1-29^{*}$ & 5 & $0,25-41^{*}$ \\
\hline Group B & 16 & 7 & 9 & 43 & $26-53$ & 32 & $25-59$ & $\left\{\begin{array}{r}1,3 \\
14,6 \\
5,1\end{array}\right.$ & $\left.\begin{array}{l}0,9-2,2+ \\
8,2-23_{+}^{+} \\
2,8-8,9^{*}\end{array}\right\}$ & $\begin{array}{r}15,3 \\
\{8,7\end{array}$ & $\begin{array}{l}8-24 \dagger \\
2-22^{*}\end{array}$ & $\begin{array}{r}11,8 \\
9,6\end{array}$ & $\begin{array}{l}1-23+ \\
1-22^{*}\end{array}$ & $\left\{\begin{array}{r}8 \\
12\end{array}\right.$ & $\begin{array}{l}2-9 \top \\
1-12 \ddagger \\
1-39^{*}\end{array}$ \\
\hline Group C & 59 & 34 & 25 & 39 & $21-70$ & 37 & $21-69$ & $\left\{\begin{array}{r}1,4 \\
11,7\end{array}\right.$ & {$\left[\begin{array}{c}0,3-3,5+ \\
4,7-20,0_{\ddagger}^{+}\end{array}\right\}$} & 14,9 & $1-32 \dagger$ & 15,7 & $4-35 \dagger$ & $\begin{array}{l}7 \\
9\end{array}$ & $\begin{array}{l}1-36 \dagger \\
2-21 \ddagger\end{array}$ \\
\hline All epileptics & 226 & 133 & 93 & 42 & $21-70$ & 37 & $21-70$ & & & & & & & & \\
\hline
\end{tabular}

TABLE II-Bone Mineral Content (B.M.C.) in Arbitrary Units (mean \pm 1 S.D.) in 127 Normal Subjects (Group 1), and Calculated Mean Total Body Calcium

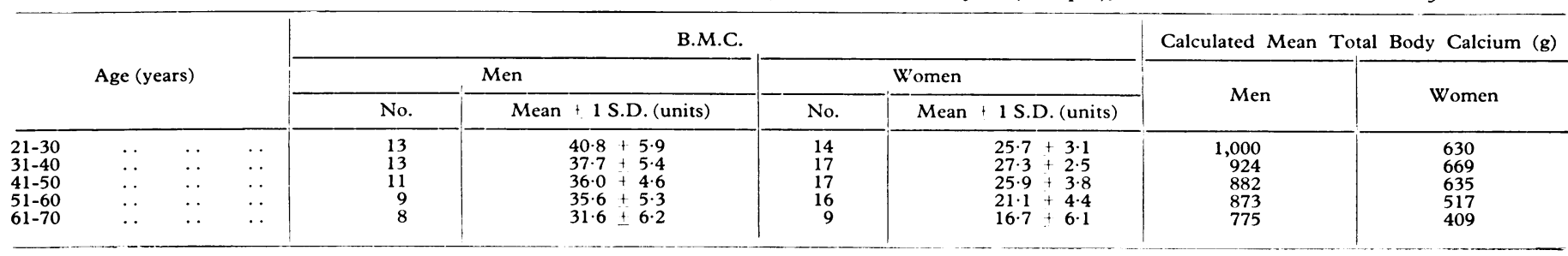

TABLE III-Age and Sex Distribution of 95 Control Subjects (Group 2) and 226 Epileptic Patients

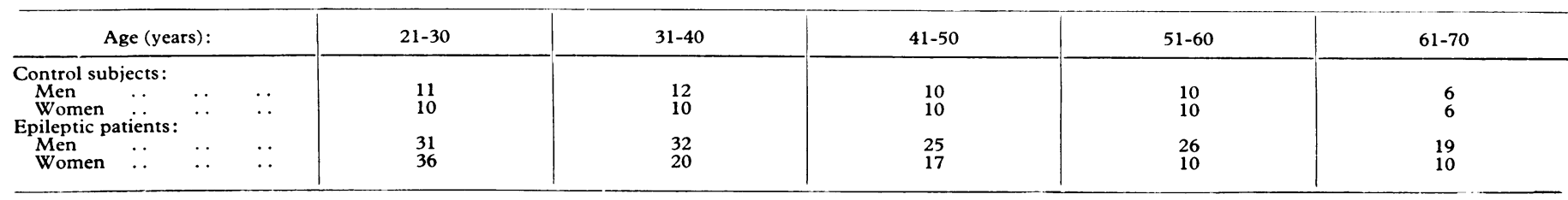



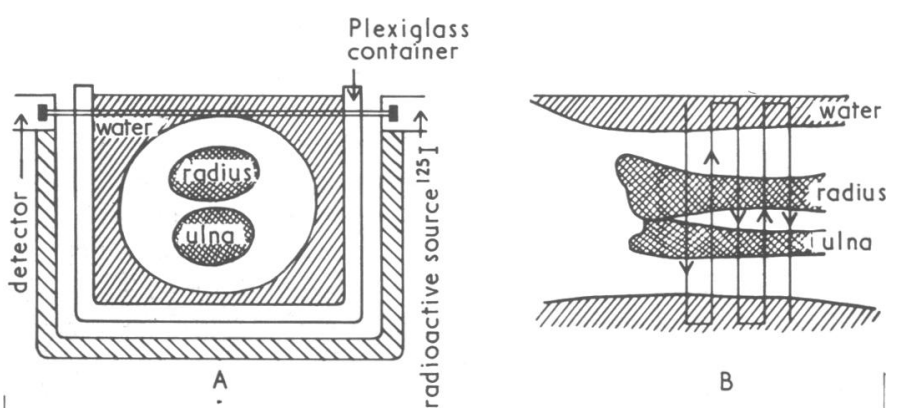

FIG. 1-Principle in measurement of bone mineral content by direct photon absorptiometry on forearm. A. section through system showing Plexiglass container, and $U$-shaped holder, with radioactive source and detector. B. System seen from volar surface, showing scanning movements of source and detector.

at each side of the bones to be examined. A mechanical scanner displaces the detector and the source perpendicular to the longitudinal axis of the bones.

The transmission of photons through the bones depends on the bone mineral content. Because the linear attentuation coefficients of Plexiglass, distilled water, and soft tissue are almost identical the measurement is independent of the amount of soft tissue. Cameron et al. (1968) showed a direct relation between the absorption of photons from ${ }^{12 .}$ I and B.M.C. In our modified version of the method (Jensen et al., 1972; Christiansen and $R \not d b r o, 1973)$ the B.M.C. is expressed in arbitrary units as a mean value of six scans from each forearm. The coefficient of variation of duplicate measurements in the same patient on different days is of the order $2-4 \%$. B.M.C. of the forearm is fairly well correlated to the body's total calcium content (Mazess, 1971; Christiansen and R $\phi$ dbro, 1973).

\section{SERUM CALCIUM AND SERUM ALKALINE PHOSPHATASE}

Blood samples were taken from all patients and the control subjects in group 2 without stasis. Serum calcium was determined by an atomic absorption spectrophotometer (PerkinElmer, 403), and serum alkaline phosphatase was determined by the method of March et al. (1959). The coefficients of variation of duplicate measurements were $1 \cdot 0^{\circ}{ }_{0}^{\prime}$ and $3 \cdot 2^{\circ}{ }_{0}^{\prime}$, respectively.

\section{SERUM PHENYTOIN AND SERUM PHENOBARBITONE}

The concentration of the anticonvulsant drugs was measured by the method of Larsen et al. (1972).

\section{PROCEDURE}

The therapeutic trial was conducted from October 1972 to February 1973. The number of sunshine hours in the Copenhagen area during this period was 312 , whereas the mean value for these five months in the years 1931 to 1960 was 264 (Danish State Institute of Meteorology, personal communication).

The same procedure was followed in the 226 epileptic patients and in the 20 normal subjects (group 3). At time $t_{0}$ (start of study) B.M.C. was determined and blood samples were drawn for determination of the serum calcium and serum alkaline phosphatase levels, and, in the epileptic patients, for determination of the serum concentration of anticonvulsants. After three months' treatment (with vitamin $\mathrm{D}_{2}$ or placebo) these measurements were repeated (at time $t_{1}$ ). All blood samples were analysed in duplicate.

After the initial B.M.C. measurement epileptic groups A, B, and $\mathrm{C}$ and group 3 of normal subjects were allocated to a "vita- min D treatment group" or a "placebo treatment group," using random sampling numbers (Bradford Hill, 1967). The number of subjects in each group is shown in table IX. The vitamin D group (116 patients and 10 controls) were treated for three months with vitamin $\mathrm{D}_{2}(2,000 \mathrm{IU} /$ day) and calcium lactate (as $390 \mathrm{mg}$ calcium/day), both drugs given by mouth. The placebo group (110 patients and 10 controls) were treated with placebo and calcium lactate (as $390 \mathrm{mg}$ calcium/day), both drugs given by mouth. The vitamin $\mathrm{D}$ and placebo tablets contained $\mathrm{CaHPO}_{4}$ (a further daily supply of $125 \mathrm{mg}$ calcium). The patients were requested to eat their usual diet during the trial, and to take no other drugs containing vitamin $\mathrm{D}$. The average daily vitamin $D$ intake from food substances in the Danish population is about 200 IU (Hansen, 1973).

In connexion with the final examination (at time $t_{1}$ ) the epileptic patients answered a simple questionnaire asking whether after three months of treatment they generally felt better, the same, or worse.

\section{PRESENTATION OF RESULTS}

The results are given separately for the population study, in which the initial measurements in the epileptic patients were compared with the values in the control groups 1 and 2 , and for the effect of treatment where the epileptic patients' initial values were compared with their final values. As B.M.C. is a function of sex and age (table II), the B.M.C. values of the epileptics were compared with the mean value and standard deviation in the corresponding sex and age group of control subjects. In the evaluation of the results the following statistical tests were used (Bradford Hill, 1967): test for difference between proportions (comparing B.M.C. distributions for epileptics with normals, initially as well as after treatment with vitamin $\mathrm{D}) ; t$ test for differences between averages (in the population study); $t$ test for pair differences (evaluating effect of treatment on B.M.C. and biochemical indices); and test for linear correlation (relations between indices of osteomalacia and "load" of anticonvulsants, and between effect of treatment and various objective criteria.)

\section{Results}

\section{POPULATION STUDY}

Bone Mineral Content.-The distribution of the B.M.C. values in the 226 epileptic patients is given in table IV. This also shows the B.M.C. values expressed as a percentage of normal values. Groups A, B, and C showed similar patterns. As a group the 226 patients had B.M.C. values lower than normal; an average of $87 \%$ of the normal value. Eighteen per cent. of the epileptic patients had values lower than mean -2 S.D. of their corresponding normal group. Only $21 \%$ of the 226 epileptics had a B.M.C. value higher than the corresponding normal mean, as opposed to the $50 \%$ in normal subjects (per definition). The standard error of the difference $(29 \%)$ between these two proportions, as calculated from the 127 normal subjects in group 1 , is $\sqrt{\frac{79 \cdot 21}{226}+\frac{50 \cdot 50}{127}}=5 \cdot 2 \%$. Accordingly, the $t$ value is $\frac{29}{5 \cdot 2}=5 \cdot 6$ $(\mathrm{P}<0.001)$. This indicates that the B.M.C. values in the normal subjects and in the epileptic patients are samples drawn from different populations-that is, that the mean B.M.C. value in the epileptics is significantly lower than normal. The findings are summarized in fig. 2 , which shows the percentage distribution of B.M.C. in the patients in relation to the normal "curve."

Serum Calcium and Serum Alkaline Phosphatase.-The distributions, mean value, and standard deviation of serum calcium levels in the epileptic groups before trial and in reference group 2 are shown in table $\mathrm{V}$. The mean serum calcium levels in grou $\mathrm{s}$ $A$ and $C$ were both significantly lower than normal $(P<0 \cdot C C 1)$, while the mean serum calcium level in group B, though low er than normal, did not differ significantly from the normal mean. 


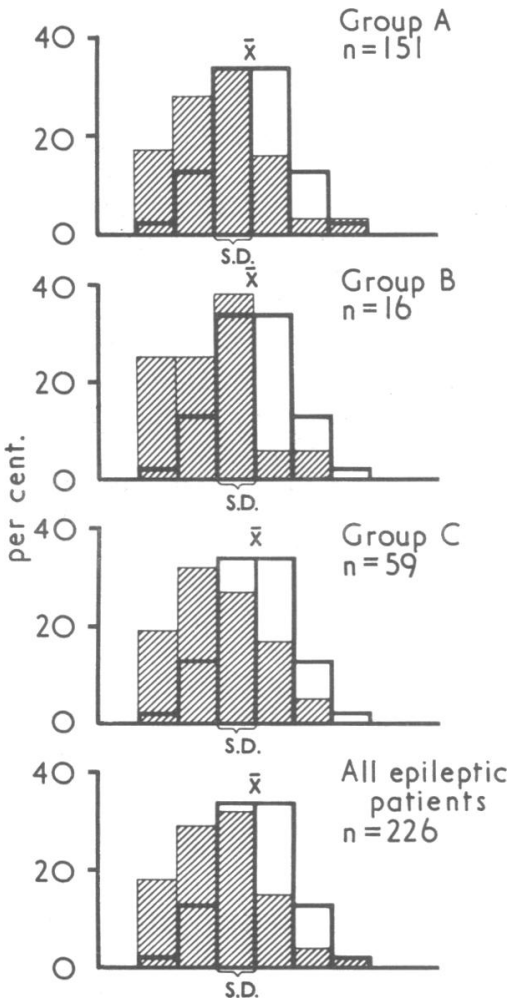

FIG. 2-Chart showing percentage distribution of bone mineral content in epileptics before treatment (hatched areas), with a class interval of one corresponding normal S.D., superimposed on ideal normal histogram (thick corresponding normal S.D., superimposed on ideal normal histogram (thick
lines). (Class interval to the left of $\bar{x}-2$ S.D.) includes all values below lines). (Class interval to the left of $\bar{x}-2$ S.D.) includes
normal mean -2 S.D.). For treatment groups, see text.

Furthermore, it was found that the mean serum calcium level in group B (phenobarbitone or primidone) was significantly higher than the mean value in group $A$ (phenytoin) $(P<0.05)$. The mean value for all 226 epileptics was significantly lower than the normal mean value $(P<0.001)$. The mean serum calcium value of the 210 patients in groups $A$ and $C-95.4 \mathrm{mg} / \mathrm{l}$. (S.D. 3.3) -was significantly lower than normal $(P<0.001)$. Of the 226 epileptics $26(12 \%)$ had serum calcium levels lower than the normal range ( $x+2$ S.D.); these all belonged to groups $\mathrm{A}$ and $\mathrm{C}$.

The distributions, mean value, and standard deviation for serum alkaline phosphatase levels in the epileptic groups before trial and in reference group 2 are shown in table VI. The mean value of 5.6 units $/ 100 \mathrm{ml}$ (S.D. 1.4) in the 49 men in group 2 was significantly higher than the mean values of 4.7 units/ $100 \mathrm{ml}$ (S.D. 1.4) in the 46 women $(P<0.001)$. The statistical tests yielded $P$ values of the same order, whether calculated from raw data or after logarithmic transformation. The mean value in the 226 epileptics was significantly higher than normal $(P<0.001)$, and 97 of them $\left(43^{\circ} \%\right)$ had serum alkaline phosphatase levels higher than the normal range $(\bar{x} \pm 2$ S.D., using corresponding normal values for men and women).

Relation between Biochemical Findings and B.M.C. Measurements. - The various combinations of normal and abnormal values of serum calcium and serum alkaline phosphatase levels are given in table VII, which also shows the corresponding mean B.M.C. values. Altogether, 111 patients $(49 \%)$ had either low serum calcium or a raised serum alkaline phosphatase level, or both. The mean B.M.C. value in these 111 patients with pathological biochemical indices of osteomalacia is $85 \%$ (S.D. $17 \%$ ). This mean value is significantly lower than the mean B.M.C. value for the patients with normal biochemical indices $(P<0.01)$.

Relation between Indices of Osteomalacia and Load of Anticonvulsants. - The coefficients of correlation between the three indices of osteomalacia (B.M.C., serum calcium, and serum alkaline phosphatase) and the "load" of anticonvulsants (dose calculated in units according to Richens and Rowe, 1970, and duration of treatment) are shown in table VIII. For the 226 epileptics a significant negative correlation was found between B.M.C. and anticonvulsant dose, and between B.M.C. and duration of anticonvulsant therapy (both $P<0.001$ ). For the two other indices of osteomalacia most correlations were not significant.

\section{EFFECT OF TREATMENT}

Bone Mineral Content.-The effect of treatment on B.M.C. in epileptic groups A, B, and C and control group 3 is shown in table IX. In each case the patients' initial B.M.C. value was expressed as $100 \%$. In the $\mathrm{A}, \mathrm{B}$, and $\mathrm{C}$ vitamin $\mathrm{D}$ groups a significant increase was found after three months' treatment. Taken

TABLE IV-Frequency Distribution of Bone Mineral Content (B.M.C.) in 226 Epileptic Patients before Trial, in Relation to B.M.C. Values in Normal Subjects (table II). Mean B.M.C. Values in Epileptics as a Percentage of Normal Values also given

\begin{tabular}{|c|c|c|c|c|c|c|c|c|c|}
\hline \multirow{2}{*}{$\begin{array}{l}\text { Treatment } \\
\text { Group }\end{array}$} & \multirow{2}{*}{$\begin{array}{c}\text { No. of } \\
\text { Patients }\end{array}$} & \multicolumn{6}{|c|}{$\begin{array}{l}\text { No. of B.M.C. Values in } 226 \text { Epileptics before Trial in Relation to Corresponding Normal Mean } \\
\qquad\left(X_{N}\right) \text { and Standard Deviation (S.D.N) }\end{array}$} & \multicolumn{2}{|c|}{$\begin{array}{l}\text { B.M.C. in Epileptics before } \\
\text { Trial (") of Corresponding } \\
\text { Normal Mean) }\end{array}$} \\
\hline & & $\bar{x}_{N}^{\text {I.ower than }}$ & \begin{tabular}{|c|} 
Between \\
$\bar{x}_{N}-1$ S.D.N \\
$\quad$ and \\
$\bar{x}_{N} \quad 2$ S.D.N.N
\end{tabular} & $\begin{array}{c}\text { Between } \\
\bar{x}_{N} \\
\text { and } \\
\bar{x}_{N}-1 \text { S.D.N. }\end{array}$ & $\begin{array}{c}\text { Between } \\
\bar{x}_{N} \\
\text { and } \\
\bar{x}_{N}+1 \text { S.D.N }\end{array}$ & $\begin{array}{c}\text { Between } \\
\bar{x}_{N}+1 \text { S.D.N } \\
\text { and } \\
\bar{x}_{N}+2 \text { S.D.N }\end{array}$ & $\begin{array}{l}\text { Higher than } \\
x_{N}+2 \text { S.D.N }\end{array}$ & $\underset{(", 0)}{\text { Mean }}$ & S.D. \\
\hline $\begin{array}{l}\text { Group A } \quad \cdots \\
\text { Group B } \quad \cdots \\
\text { Group C } \\
\text { All epileptics }\end{array}$ & $\begin{array}{r}151 \\
16 \\
59 \\
226\end{array}$ & $\begin{array}{r}24 \\
4 \\
11 \\
39\end{array}$ & $\begin{array}{r}44 \\
4 \\
19 \\
67\end{array}$ & $\begin{array}{r}51 \\
6 \\
16 \\
73\end{array}$ & $\begin{array}{r}24 \\
1 \\
10 \\
35\end{array}$ & $\begin{array}{l}4 \\
1 \\
3 \\
8\end{array}$ & $\begin{array}{l}4 \\
0 \\
0 \\
4\end{array}$ & $\begin{array}{l}89 \\
84 \\
87 \\
87\end{array}$ & $\begin{array}{l}17 \\
13 \\
17 \\
16\end{array}$ \\
\hline
\end{tabular}

TABLE v-Frequency Distribution of Serum Calcium Level in 226 Epileptics before Trial and in 95 Normal Subjects

\begin{tabular}{|c|c|c|c|c|c|c|c|c|c|c|c|c|c|c|c|}
\hline \multirow{2}{*}{\multicolumn{2}{|c|}{$\begin{array}{l}\text { Treatment } \\
\text { Group }\end{array}$}} & \multirow[b]{2}{*}{$\begin{array}{l}\text { No. of } \\
\text { Patients }\end{array}$} & \multicolumn{10}{|c|}{ Serum Calcium Level (mg/l.) } & \multirow[b]{2}{*}{ Mean } & \multirow[b]{2}{*}{ S.D. } & \multirow{2}{*}{$\begin{array}{l}\text { Significance of } \\
\text { Difference from } \\
\text { Normal }\end{array}$} \\
\hline & & & $<90 \cdot 0$ & $\begin{array}{c}90 \cdot 0 \\
\text { to } \\
91 \cdot 9\end{array}$ & $\begin{array}{l}92 \cdot 0 \\
\text { to } \\
93 \cdot 9\end{array}$ & $\begin{array}{l}94 \cdot 0 \\
\text { to } \\
95 \cdot 9\end{array}$ & $\begin{array}{c}96 \cdot 0 \\
\text { to } \\
97 \cdot 9\end{array}$ & $\begin{array}{c}98 \cdot 0 \\
\text { to } \\
99 \cdot 9\end{array}$ & $\begin{array}{l}100 \cdot 0 \\
\text { to } \\
101.9\end{array}$ & $\begin{array}{c}102 \cdot 0 \\
\text { to } \\
103 \cdot 9\end{array}$ & $\begin{array}{l}104 \cdot 0 \\
\text { to } \\
105 \cdot 9\end{array}$ & $\begin{array}{l}106.0 \\
\text { to } \\
107.9\end{array}$ & & & \\
\hline $\begin{array}{ll}\text { Group A } & \ldots \\
\text { Group B } & \\
\text { Group C } & . \\
\end{array}$ & $\begin{array}{l}\cdots \\
\cdots \\
\cdots\end{array}$ & $\begin{array}{r}151 \\
16 \\
59 \\
\end{array}$ & $\begin{array}{l}6 \\
0 \\
1 \\
\end{array}$ & $\begin{array}{r}12 \\
0 \\
7 \\
\end{array}$ & $\begin{array}{r}28 \\
1 \\
12 \\
\end{array}$ & $\begin{array}{r}38 \\
5 \\
13 \\
\end{array}$ & $\begin{array}{r}33 \\
2 \\
13 \\
\end{array}$ & $\begin{array}{r}21 \\
5 \\
8 \\
\end{array}$ & $\begin{array}{l}8 \\
2 \\
3 \\
\end{array}$ & $\begin{array}{l}3 \\
1 \\
0 \\
\end{array}$ & $\begin{array}{l}2 \\
0 \\
2 \\
\end{array}$ & $\begin{array}{l}0 \\
0 \\
0 \\
\end{array}$ & $\begin{array}{l}95 \cdot 3 \\
97 \cdot 2 \\
95 \cdot 5\end{array}$ & $\begin{array}{l}3 \cdot 2 \\
2 \cdot 8 \\
3 \cdot 4\end{array}$ & $\begin{array}{l}P<0.001 \\
\text { N.S. } \\
P<0.001\end{array}$ \\
\hline All epileptics & .. & 226 & 7 & 19 & 41 & 56 & 48 & 34 & 13 & 4 & 4 & 0 & $95 \cdot 6$ & $3 \cdot 3$ & $P<0.001$ \\
\hline $\begin{array}{l}\text { Normal subjects } \\
\text { (Group 2) }\end{array}$ & .. & 95 & 2 & 1 & 2 & 12 & 15 & 23 & 19 & 14 & 6 & 1 & $99 \cdot 0$ & $3 \cdot 5$ & \\
\hline
\end{tabular}

N.S. $=$ Not significant $(P>0.05)$ 
as a whole the 116 epileptics on vitamin $\mathrm{D}$ showed an average increase of about $4 \%$. The B.M.C. values in the control group treated with vitamin $D$ did not rise (mean value after treatment $99.8 \%$ of initial value). In the placebo group the mean B.M.C. values remained virtually unchanged during the study (mean values: group $\mathrm{A}, 100.0 \%$; group $\mathrm{B}, 99.9 \%$; group $\mathrm{C}, 100.5 \%$; all 110 epileptics, $100 \cdot 1 \%$; control subjects, $99 \cdot 1 \%$ ). The effect of treatment in the epileptic patients is summarized in fig. 3 .

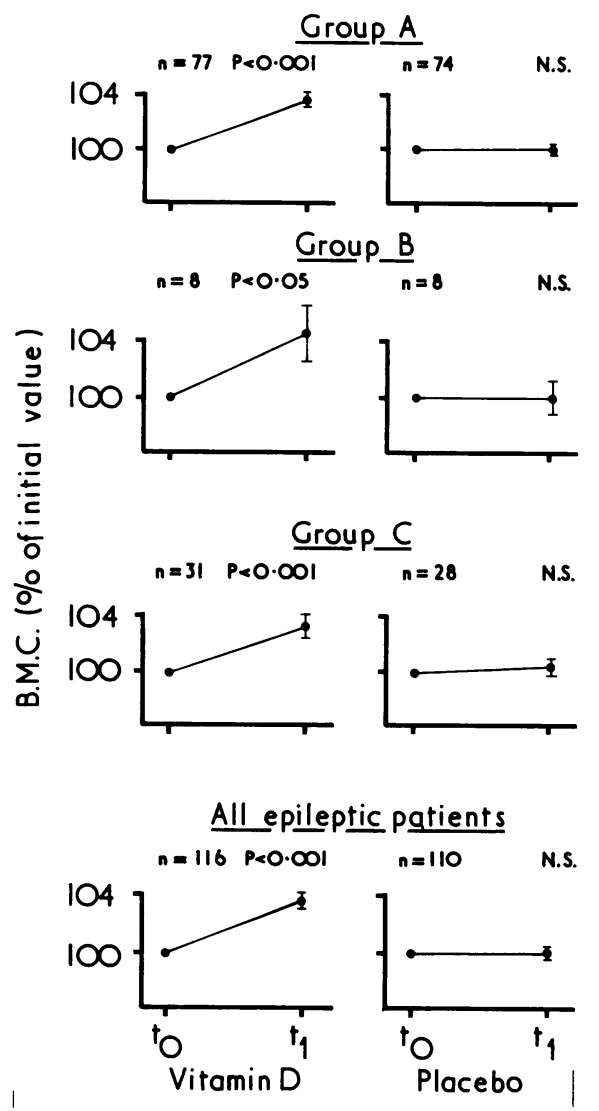

FIG. 3-Effect on bone mineral content (B.M.C.) of three months' treatment with vitamin $\mathrm{D}_{2}$ plus calcium (left) and placebo plus calcium (right). B.M.C. expressed as $100 \%$ at time $t_{0}$ and as percentage of initial value $( \pm 1$ S.E. of mean) three months later, at time $t_{1}$. N.S. = Not significant. For treatment groups, see text.
By taking the mean B.M.C. value in young normal males (table II) to represent a total body calcium of $1,000 \mathrm{~g}$ the mean total body calcium values were calculated in the various subgroups of the therapeutic trials (table IX). The 116 epileptics on vitamin $\mathrm{D}$ showed an average increase of $23 \mathrm{~g}$ over the three months of treatment-that is, a mean daily positive calcium balance of $0.3 \mathrm{~g}$. The mean value of calculated total body calcium in the 110 epileptics on placebo treatment was $641 \mathrm{~g}$ both before and after the trial. The distribution of B.M.C. values before and after treatment in the 116 epileptics treated with vitamin D is given in table X. Before treatment 15 patients were below the normal range and only $30(26 \%)$ were higher than the corresponding normal mean. After treatment nine patients were below the normal range and $37(32 \%)$ were higher than the corresponding normal mean. The B.M.C. values had thus increased, but not reached normal levels. The difference between the normal $50 \%$ and the $32 \%$ in the patients above the normal mean is $18 \%$. The standard error of this difference is $\sqrt{\frac{68 \cdot 32}{116}+\frac{50 \cdot 50}{127}}=6 \cdot 2 \%$. The $t$ value is $\frac{18}{6 \cdot 2}=2 \cdot 9(\mathrm{P}<0.01)$. This calculation bears out that the increase in B.M.C. caused by vitamin D had not led to a return to normal levels of the B.M.C. values in the epileptic patients.

Serum Calcium and Serum Alkaline Phosphatase.-The effect of treatment on serum calcium and serum alkaline phosphatase is shown in table XI. A significant change was found only for serum calcium level in group A with vitamin D. For the 116 epileptics in the vitamin $\mathrm{D}$ group the mean serum calcium level rose $0.3 \mathrm{mg} / \mathrm{l}$. and the mean serum alkaline phosphatase level fell 0.3 K.A. units $/ 100 \mathrm{ml}$, but neither of these changes were significant.

Relation between Effect of Treatment and Various other Factors.-The relations between effect of treatment (expressed as the ratio between the individual B.M.C. values after and before treatment) and clinical data, load of anticonvulsants, and the three indices of osteomalacia are given in table XII. The only significant correlation was for the initial B.M.C. value, in such a way that a low initial value tended towards a high increase in B.M.C. during treatment with vitamin D.

Questionnaire.-Out of the 116 epileptic patients who received treatment with vitamin D 19 answered after completion of the study that they generally felt better, 88 felt generally the same, and nine felt generally worse. The corresponding figures for the 110 patients in the placebo group were: 25,70 , and 15 . Thus, the treatment with vitamin $\mathrm{D}$ in the given dosage for three months had no influence on the patients' feeling of wellbeing.

TABLE vi-Frequency Distribution of Serum Alkaline Phosphatase Level in 226 Epileptics before Trial and in 95 Normal Subjects

\begin{tabular}{|c|c|c|c|c|c|c|c|c|c|c|c|c|c|c|c|}
\hline \multirow{2}{*}{\multicolumn{2}{|c|}{$\begin{array}{l}\text { Treatment } \\
\text { Group }\end{array}$}} & \multirow{2}{*}{$\begin{array}{c}\text { No. of } \\
\text { Patients }\end{array}$} & \multicolumn{10}{|c|}{ Serum Alkaline Phosphatase Level (K.A. units/100 ml) } & \multirow{2}{*}{ Mean } & \multirow{2}{*}{ S.D. } & \multirow{2}{*}{$\begin{array}{c}\text { Significance of } \\
\text { Difference from } \\
\text { Normal }\end{array}$} \\
\hline & & & $\begin{array}{l}2 \cdot 1 \\
\text { to } \\
3 \cdot 0\end{array}$ & $\begin{array}{c}3 \cdot 1 \\
\text { to } \\
4 \cdot 0\end{array}$ & $\begin{array}{c}4 \cdot 1 \\
\text { to } \\
5 \cdot 0\end{array}$ & $\begin{array}{l}5 \cdot 1 \\
\text { to } \\
6 \cdot 0\end{array}$ & $\begin{array}{l}6 \cdot 1 \\
\text { to } \\
7 \cdot 0\end{array}$ & $\begin{array}{l}7 \cdot 1 \\
\text { to } \\
8 \cdot 0\end{array}$ & $\begin{array}{c}8 \cdot 1 \\
\text { to } \\
9 \cdot 0\end{array}$ & $\begin{array}{c}9 \cdot 1 \\
\text { to } \\
10 \cdot 0\end{array}$ & $\begin{array}{l}10 \cdot 1 \\
\text { to } \\
11 \cdot 0\end{array}$ & $>11 \cdot 1$ & & & \\
\hline $\begin{array}{cc}\text { Group A } & \cdots \\
\text { Group B } & \cdots \\
\text { Group C } & \cdots\end{array}$ & $\begin{array}{l}\cdots \\
\cdots\end{array}$ & $\begin{array}{r}151 \\
16 \\
59\end{array}$ & $\begin{array}{l}0 \\
0 \\
0\end{array}$ & $\begin{array}{l}6 \\
1 \\
1\end{array}$ & $\begin{array}{l}7 \\
1 \\
6\end{array}$ & $\begin{array}{r}18 \\
1 \\
7\end{array}$ & $\begin{array}{r}17 \\
3 \\
7\end{array}$ & $\begin{array}{r}31 \\
4 \\
11\end{array}$ & $\begin{array}{r}22 \\
5 \\
6\end{array}$ & $\begin{array}{r}14 \\
0 \\
7\end{array}$ & $\begin{array}{r}11 \\
1 \\
6\end{array}$ & $\begin{array}{r}25 \\
0 \\
8\end{array}$ & $\begin{array}{l}8 \cdot 2 \\
7 \cdot 3 \\
8 \cdot 4\end{array}$ & $\begin{array}{l}2 \cdot 5 \\
2 \cdot 0 \\
2 \cdot 7\end{array}$ & $\begin{array}{l}P<0.001 \\
P<0.001 \\
P<0.001\end{array}$ \\
\hline All epileptics & $\cdots$ & 226 & 0 & 8 & 14 & 26 & 27 & 46 & 33 & 21 & 18 & 33 & $8 \cdot 1$ & $2 \cdot 6$ & $P<0.001$ \\
\hline $\begin{array}{l}\text { Normal subjects } \\
\quad \text { (group 2) }\end{array}$ & 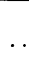 & 95 & 5 & 16 & 31 & 23 & 12 & 4 & 2 & 2 & 0 & 0 & $5 \cdot 1$ & 1.4 & \\
\hline
\end{tabular}

TABLE VII-Combinations of Biochemical Findings in Relation to Bone Mineral Content (B.M.C.) Values in 226 Epileptics

\begin{tabular}{|c|c|c|c|c|c|}
\hline \multicolumn{3}{|c|}{ Combinations of Biochemical Findings } & \multicolumn{2}{|c|}{ B.M.C. ( $\%$ of Corresponding Normal Mean) } & \multirow{2}{*}{$\begin{array}{l}\text { No. of Epileptics with B.M.C. lower } \\
\text { than } \bar{x}_{N}-2 \text { S.D.N }\end{array}$} \\
\hline$\underset{\substack{\text { Calcium } \\
\text { Level }}}{\text { Carum }}$ & $\begin{array}{c}\text { Serum Alkaline } \\
\text { Phosphatase } \\
\text { Level }\end{array}$ & No. of Patients & Mean & S.D. & \\
\hline $\begin{array}{l}\text { Normal } \\
\text { Normal } \\
\text { Abnormal } \\
\text { Abnormal }\end{array}$ & $\begin{array}{l}\text { Normal } \\
\text { Abnormal } \\
\text { Normal } \\
\text { Abnormal }\end{array}$ & $\begin{array}{r}115 \\
85 \\
14 \\
12\end{array}$ & $\begin{array}{l}92 \\
85 \\
82 \\
84\end{array}$ & $\begin{array}{l}16 \\
17 \\
13 \\
20\end{array}$ & $\begin{array}{r}14 \\
19 \\
4 \\
2\end{array}$ \\
\hline
\end{tabular}

$\bar{x}_{N}=$ Mean value of corresponding control group.

S.D.N $=$ Standard deviation of corresponding control group.
N 


\section{Discussion}

With our method of determining B.M.C. a special technique is used to ensure that the same part of the patient's forearm is measured at each study (Jensen et al., 1972; Christiansen and $\mathrm{R} \not d$ dbro, 1973). This is important for the good reproducibility of the method. The parameter used for B.M.C. (in arbitrary units) is related to the weight and calcium content of the bones in the forearm with very high coefficients of correlation (Christiansen and Rpdbro, 1973) and is also well correlated to the weight of the total skeleton ( $r 0.90$, Mazess, 1971). Therefore the fundamental assumption seems reasonable that the parameter of B.M.C. used is related to total body calcium (tables II and IX). W'ith this relation and the good reproducibility the measurement of B.M.C. yields an opportunity to quantitate

TABLE vili-Coefficients of Correiations between Indices of Osteomalacia (Bone Mineral Content, Serum Levels of Calcium, and Alkaline Phosphatase) and Load of Anticonvulsants (Dose and Duration of Treatment) from 226 Epileptics

\begin{tabular}{|c|c|c|c|c|c|c|c|c|}
\hline & \multicolumn{8}{|c|}{ Load of Anticonvulsants } \\
\hline & \multicolumn{4}{|c|}{ Dose* } & \multicolumn{4}{|c|}{ Duration of Treatment } \\
\hline & $\begin{array}{l}\text { Group A } \\
(\mathrm{n}=151)\end{array}$ & $\begin{array}{l}\text { Group B } \\
(\mathrm{n}=16)\end{array}$ & $\begin{array}{l}\text { Group C } \\
(\mathrm{n}=59)\end{array}$ & $\begin{array}{l}\text { All Epileptics } \\
(\mathrm{n}=226)\end{array}$ & $\begin{array}{c}\text { Group } A \\
(\mathrm{n}=151)\end{array}$ & $\begin{array}{l}\text { Group B } \\
(\mathrm{n}=16)\end{array}$ & $\begin{array}{l}\text { Group C } \\
(\mathrm{n}=59)\end{array}$ & $\begin{array}{l}\text { All Epileptics } \\
(\mathrm{n}=226)\end{array}$ \\
\hline $\begin{array}{l}\text { Indices of osteomalacia: } \\
\text { Bone mineral content as per cent. } \\
\text { of corresponding normal mean .. }\end{array}$ & $\begin{array}{c}r_{P}=--0.21, \\
P<0.02\end{array}$ & 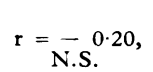 & $\mathrm{r}=\frac{-0.07}{\text { N.S. }}$ & $\begin{array}{c}r_{P}=0.001 \\
P<0.24\end{array}$ & $\begin{array}{l}r=-0.24, \\
P<0.01\end{array}$ & $\mathrm{r}=-0.35$ & $\begin{array}{c}\mathbf{r}=-0.31 \\
\mathbf{P}<0.02\end{array}$ & $\begin{array}{r}\mathbf{r}_{\mathbf{P}}=-0.001 \\
<<0.001\end{array}$ \\
\hline & $r=N^{0 . S .01}$ & $r=\frac{-0.35}{\text { N.S. }}$ & $r=-\frac{0.24}{\text { N.S. }}$ & $\mathrm{r}=\mathrm{N}^{\mathrm{S} .} \mathrm{.}^{0.01}$ & $r=S^{0.06}$ & $\mathrm{r}=\mathrm{N} . \mathrm{S} .^{0.02}$ & $\mathrm{r}=-0.22$, & $r=-0.06$ \\
\hline Serum alkaline phosphatase level & $\begin{array}{c}\mathrm{r}=0.15, \\
\text { N.S. }\end{array}$ & $\begin{array}{l}r=0.09, \\
\text { N.S. }\end{array}$ & $\begin{array}{l}\mathrm{r}=0.57 \\
\mathrm{P}<0.001\end{array}$ & $\begin{array}{l}\mathrm{r}=0.15 \\
\mathrm{P}<0.05\end{array}$ & $\begin{array}{l}r=0.04 \\
\text { N.S. }\end{array}$ & $\begin{array}{c}r=0 \cdot 10, \\
\text { N.S. }\end{array}$ & $\begin{array}{l}r=0.09, \\
\text { N.S. }\end{array}$ & $\begin{array}{c}\mathrm{r}=\mathrm{C} \cdot 03, \\
\text { N.S. }\end{array}$ \\
\hline
\end{tabular}

* Dose calculated in units according to Ricinens and Rowe (1970).
N.S. = Not significant $(\mathbf{P}>0.05)$.

TABLE IX-Bone Mineral Content (B.M.C.) in 226 Epileptics after Treatment for Three Months with Calcium plus Vitamin D or Calcium plus Placebo, and Calculated Mean Total Body Calcium before and after Trial

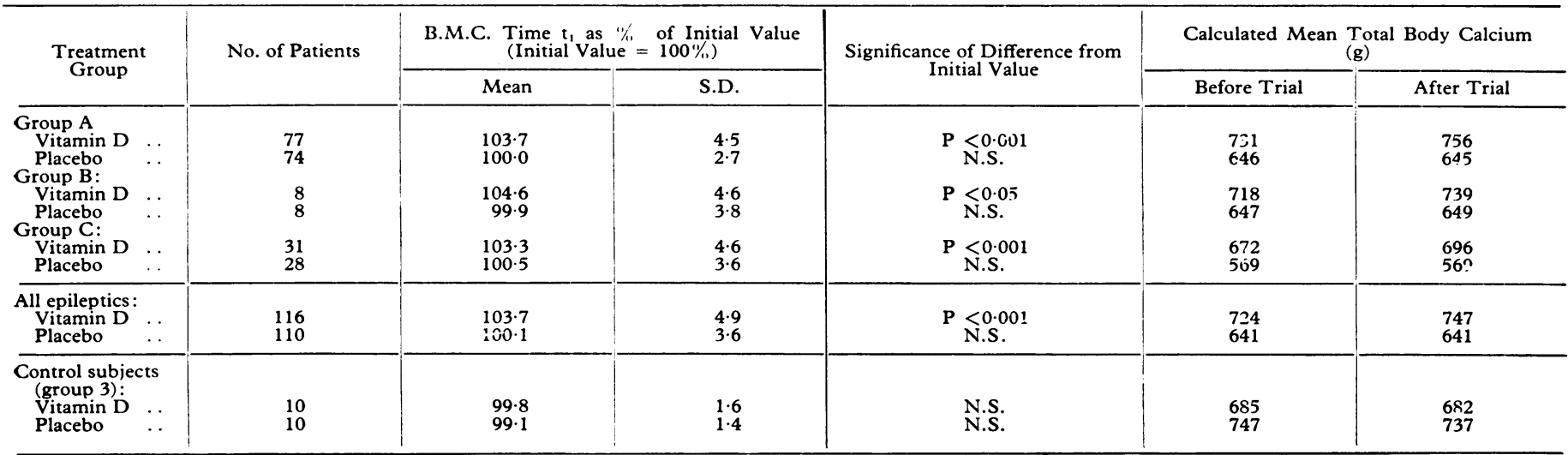

N.S. $=$ Not significant $(P>0.05)$.

TABLE x-Bone Mineral Content (B.M.C.) in 116 Epileptics in Vitamin D Group before and after Three Months' Vitamin D Treatment. B.M.C. Values Expressed as Frequency Distribution in Relation to B.M.C. Values of Corresponding Control Subjects and as Mean Value as Percentage of Corresponding Control Group

\begin{tabular}{|c|c|c|c|c|c|c|c|c|c|c|}
\hline & & \multirow{2}{*}{$\begin{array}{l}\text { No. of } \\
\text { Patients }\end{array}$} & No. of B.M.C. & \multicolumn{5}{|c|}{$\begin{array}{l}\text { Values before and after Trial in Relation to Corresponding Normal Mean }\left(\bar{x}_{N}\right) \text { and } \\
\text { Standard Deviation (S.D.N) }\end{array}$} & \multicolumn{2}{|c|}{$\begin{array}{l}\text { B.M.C. in Epileptics before and } \\
\text { after Trial ( } y_{1} \text { of Correspond- } \\
\text { ing Normal Mean) }\end{array}$} \\
\hline & & & $\begin{array}{l}\text { Lower than } \\
\bar{x}_{N}-2 \text { S.D.N }\end{array}$ & \begin{tabular}{|} 
Between \\
$\bar{x}_{N}-1$ S.D.N \\
$\bar{x}_{N}-2$ S.D.N
\end{tabular} & $\begin{array}{c}\text { Between } \\
\widetilde{x}_{N} \\
\text { and } \\
\bar{x}_{N}-1 \text { S.D.N.N }\end{array}$ & $\left|\begin{array}{c}\text { Betwween } \\
x_{N} \\
\text { and } \\
\bar{x}_{N}+2 \text { S.D.N.N }\end{array}\right|$ & \begin{tabular}{|c|} 
Between \\
$\bar{x}_{N}+1$ S.D.N \\
and \\
$\bar{x}_{N}+2$ S.D.N.N
\end{tabular} & $\begin{array}{l}\text { Higher than } \\
\bar{x}_{\mathrm{N}}+2 \text { S.D.N }\end{array}$ & Mean & S.D. \\
\hline $\begin{array}{l}\text { Before trial } \\
\text { After trial .. }\end{array}$ & $\therefore$ & $\begin{array}{l}116 \\
116\end{array}$ & $\begin{array}{r}15 \\
9\end{array}$ & $\begin{array}{l}29 \\
30\end{array}$ & 42 & $\begin{array}{l}24 \\
30\end{array}$ & $\begin{array}{l}4 \\
5\end{array}$ & 2 & $\begin{array}{l}90 \\
93\end{array}$ & $\begin{array}{l}16 \\
16\end{array}$ \\
\hline
\end{tabular}

TABLE XI-Difference from Initial Values of Serum Calcium and Serum Alkaline Phosphatase in 226 Epileptics after Treatment for Three Months with Calcium plus Vitamin D or Calcium plus Placebo

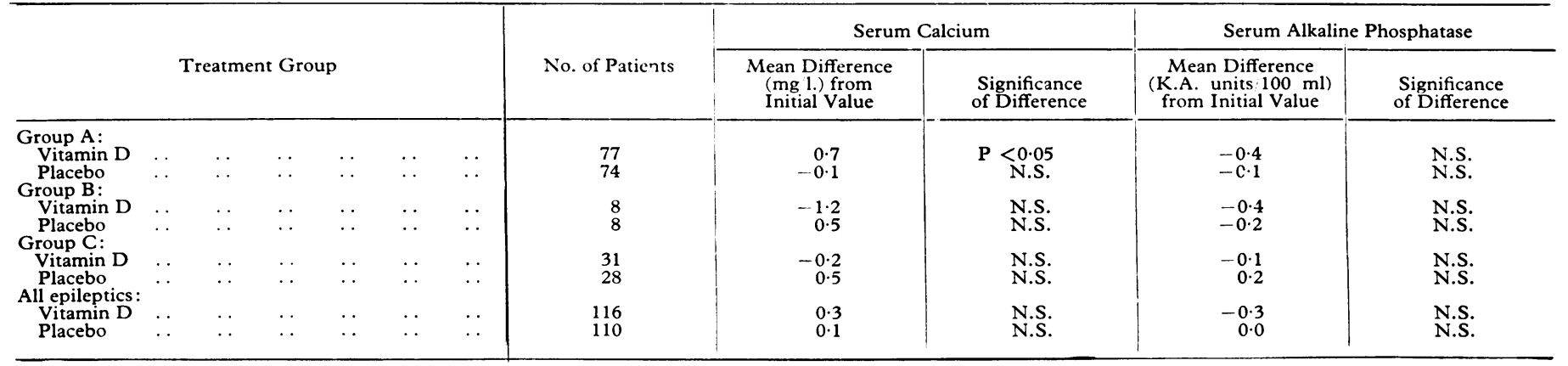

N.S. $=$ Not significant $(P>0.05)$. 
TABLE XII-Coefficients of Correlation between Effect of Treatment with Vitamin D on Bone Mineral Content (B.M.C.) and Clinical Data, Load of Anticonzulsants, and Indices of (Osteomalacia in 116 Epileptics.

\begin{tabular}{|c|c|c|c|c|c|c|c|}
\hline \multirow[b]{2}{*}{ Effect of treatment: } & \multicolumn{2}{|c|}{ Clinical Data } & \multicolumn{2}{|c|}{ Load of Anticonvulsants } & \multicolumn{3}{|c|}{ Indices of Osteomalacia } \\
\hline & Age & Body Weight & Dose & $\begin{array}{c}\text { Duration of } \\
\text { Therapy }\end{array}$ & $\begin{array}{l}\text { Initial Serum } \\
\text { Calcium Value }\end{array}$ & $\begin{array}{l}\text { Initial Serum } \\
\text { Alkaline Phos- } \\
\text { phatase Value }\end{array}$ & $\frac{B M C t_{0}}{\bar{x}_{N}}$ \\
\hline$\frac{\text { B.M.C. } t_{1}}{\text { B.M.C. } t_{11}}$ & $\begin{aligned} r= & 0 \cdot 19, \\
& \text { N.S. }\end{aligned}$ & $\begin{array}{c}r=0.06, \\
\text { N.S. }\end{array}$ & $\begin{array}{c}r=0.00, \\
\text { N.S. }\end{array}$ & $\begin{array}{l}\mathrm{r}=0.07, \\
\text { N.S. }\end{array}$ & $r={ }^{N} . S^{0.02,}$ & $\begin{aligned} & \mathrm{r}=0.12, \\
& \text { N.S. }\end{aligned}$ & $\begin{array}{r}r=-0.28 \\
P<0.01\end{array}$ \\
\hline
\end{tabular}

B.M.C. $t_{1}=$ Bone mineral content after trial.
B.M.C. $t_{1}=$ Bone mineral content before tria

B.M.C. $t_{11}=$ Bone mineral content before trial.

$\bar{X}_{N}=$ Mean value in cor
N.S. = Not significant.

the bone effect of vitamin $\mathrm{D}$ in patients with anticonvulsant osteomalacia.

The present findings indicate that all three groups of epileptics had similarly low B.M.C. values. On average the epileptics' total body calcium could be estimated at $87 \%$ of normal. About one-fifth had subnormal B.M.C. values. The degree of demineralization was related to the dose and duration of anticonvulsant therapy. Richens and Rowe (1970) found a correlation between the biochemical indices of osteomalacia and the dose of anticonvulsant.

As to the effect of the treatment, the results clearly showed that the B.M.C. rose in all epileptic groups in response to vitamin $\mathrm{D}$, with an average increase of $4 \%$. When the unchanged values in the control subjects (group 3) and the epileptics on placebo are considered the calculated positive calcium balance of $23 \mathrm{~g}$ over the three months could be ascribed to the daily therapeutic dose of $2,000 \mathrm{IU}$ vitamin $\mathrm{D}_{2}$. These results confirm our previous preliminary communications (Christiansen et al., 1972; Christiansen et al., 1973), but disagree with the findings of Linde et al. (1972). They were unable to find any effect on B.M.C. in nine patients who received 50,000 IU vitamin $\mathrm{D}$ daily for six months without supplementary calcium intake. This dose of vitamin D may have been too large.

Previous reports on epileptic inpatients have shown an incidence of hypocalcaemia of $23^{\prime \prime}{ }^{\prime}$ and $30^{\circ}{ }^{\circ}$. (Richens and Rowe, 1970; Hunter et al., 1971) and $19^{\circ},{ }^{\prime \prime}$ for outpatients Hahn et al., 1972). We found an incidence of $12^{\circ}{ }_{0}$. These disparities may be due to sampling from different populations and varying criteria for selection. Since the "non-response" sample in the present series was rather small our patients may be regarded as fairly representative of an epileptic outpatient population.

The incidence of raised serum alkaline phosphatase levels in epileptic inpatients on long-term anticonvulsant therapy has been reported to be $29^{\circ}{ }^{\prime \prime}$ and $24^{\circ}{ }^{\circ}$ (Richens and Rowe, 1970; Hunter et al., 1971). In contrast to these reports we have found that $43 \%$ had increased values. The normal range calculated from our 95 group 2 control subjects was narrower than that given by Richens and Rowe (1970) in 82 subjects with a mean age of 34 years. This disparity is difficult to explain. However, by using the upper limit reported by Richens and Rowe (10 and $12 \mathrm{~K} . \mathrm{A}$. units $/ 100 \mathrm{ml}$ for women and men, respectively) the incidenze of raised serum alkaline phosphatase in our series fell to $12^{\prime \prime \prime}$ ( 27 of the 226 patients).

The data given in table VII show that the biochemical and bone indices of osteomalacia are related. Furthermore, our results show that whereas these indices are supplementary to diagnosis of pathological conditions in anticonvulsant osteomalacia, the measurement of B.M.C. is the more sensitive index to evaluate treatment with vitamin $\mathrm{D}$.

Osteomalacia is said to give various vague general symptoms. The answers to the questionnaire revealed that the patients felt no subjective improvement; this, however, is inconclusive, since the dose of vitamin $D$ was rather small and given for only a limited period.

From the present controlled therapeutic trial in a large representative sample of epileptic outpatients it can be concluded that such patients have a lower than normal total body calcium, which over three months can be increased, but not to normal levels, by a relatively small daily vitamin $\mathrm{D}_{2}$ supplement. The question whether epileptics prophylactically should receive vitamin $\mathrm{D}$ is a cost-benefit problem which cannot be answered from the present study. The incidence of pathological findings in the various indices of osteomalacia in this and other reports is, however, noteworthy. If not all patients should be treated prophylactic vitamin $\mathrm{D}$ treatment might be appropriate at least in those with subnormal B.M.C. values. Present knowledge concerning anticonvulsant osteomalacia necessitates close supervision of epileptics by all clinicians with such patients under their care.

Our thanks are due to Mrs. Birie Jørgensen, who did most of the B.M.C. measurements; Mrs. Hanne Foltved, Mrs. Inge Madsen, Mrs. Kirsten Neilsen, Miss Ingelise Petersen, Mrs. Lise Smith, Miss Kirsten Voldmester, and Mrs. Inger Wätjen for valuable technical help; Mr. N. E. Larsen for determination of serum an:iconvulsant concentrations; the Pharmacy of Copenhazen County Hospitals for preparation of vitamin D and placebo drugs; Mrs. Edel Damgaard, Miss Dagny Hansen, Miss Dorthe Helmer, and Miss Vibeke Nygaard for secretarial help; the Danish Epilepsy Association for financial support; and the 226 patients from the epilepsy clinic at Glostrup Hospital who willingly took part in the trial.

\section{References}

Berger, G., and Munde, B. (1970). Deutsche Gesundheitswesen, 15, 1549 Bogan, J., and Smith, H. (1968). Fournal of Pharmacy and Pharmacology, 20, 64 .

Bradford Hill, A. (1967). Principles of Medical Statistics, 8th edn. London,

Lameron, J. R., Mazess, R. B., and Sorensen, J. A. (1968). Investigative Radiology, 3, 141 .

Radiology, 3, 141 .
Christiansen, C., Kristensen, M., and R\&dbro, P. (1972). British Medical fournal, 3, 738 .

Christiansen, C., R\$dbro, P., and Lund, M. (1973). British Medical fournal, $2,208$.

Christiansen, C., and R\&dbro, P. (1973). To be published.

Dent, C. E., Richens, A., Rowe, D. J. F., and Stamp, T. C. B. (1970). British Medical fournal, 4, 69.

Hahn, T. J., Hendin, B. A., Scharp, C. R., and Haddad, J. G. (1972). New England fournal of Medicine, 287, 900.

Hansen, K. M. (1973). Husholdningsrådets Tekniske Meddelelser, 2, 16.

Hunter, J., Maxwell, J. D., Stewart, D. A., Parsons, V., and Williams, R. (1971). British Medical fournal, 4, 202.

Jensen, H., Christiansen, C., Lindbjerg, I. F., and Munck, O. (1972). Acta Radiologica, Suppl. No. 313, p. 214.

Kruse, R. (1968). Monatsschrift für Kinderheilkunde, 116, 378.

Larsen, N. E., Naestoft, J., and Hvidberg, E. (1972). Clinica Chimica Acta,

40, 171.
Lässker, G., Degen, R., Köthe, C. (1971). Confinia Neurologica, 33, 55.

Lässker, G., Degen, R., Köthe, C. (1971). Confinia Neurologica, 33, 55.
Linde, J., Hansen, J. M., Siersbaek-Nielsen, K., and Fuglsang-Frederiksen, V. (1971). Acta Neurologica Scandinavica, 47, 650 .

Linde, J., Hansen, J. M., Siersbaek-Nielsen, K., and Fuglsang-Frederiksen, V. (1972). British Medical fournal, 4, 547.

Lussier-Lazaroff, J., and Fletcher, B. D. (1971). Journal of the Canadian Association of Radiologists, 22, 144.

March, W. H., Fingerhut, B., and Kirsch, E. (1959). Clinical Chemistry, 5, 119.

Mazess, R. B. (1971). Investigative Radiology, 6, 52.

Ponchon, G., and DeLuca, H. F. (1969). The Journal of Clinical Investigations, 48, 1273.

Richens, A., and Rowe, J. F. (1970). British Medical fournal, 4, 73.

Schmid, F. (1967). Fortschritte der Medizin, 9, 381.

Stamp, T. C. B., Round, J. M., Rowe, D. J., and Haddad, J. G. (1972). British Medical fournal, 4, 9.

Stögmann, W. (1971). Pädiatric und Pädologic, 6, 280

Wright, J. A. (1965). Epilipsia, 6, 67. 